\title{
Incidence of hepatitis B surface antigen among sickle cell disease patients receiving transfusion therapy
}

\author{
Samuel S. Antwi-Baffour ${ }^{1, ~}$, Kwadwo Adarkwah-Yiadom ${ }^{2}$, Ransford Kyeremeh ${ }^{1}$, \\ David Nana Adjei ${ }^{1}$, Mahmood S. Abdulai ${ }^{1}$, Patrick F. Ayeh-Kumi ${ }^{1}$ \\ ${ }^{1}$ Department of Medical Laboratory Sciences, School of Allied Health Sciences, College of Health Sciences, University of Ghana, Korle- \\ $\mathrm{Bu}$, Accra, Ghana \\ ${ }^{2}$ The Central Laboratory, Korle-bu Teaching Hospital, Accra, Ghana
}

Email address:

s.antwi-baffour@chs.edu.gh (S. S. Antwi-Baffour)

\section{To cite this article:}

Samuel S. Antwi-Baffour, Kwadwo Adarkwah-Yiadom, Ransford Kyeremeh, David Nana Adjei, Mahmood S. Abdulai, Patrick F. AyehKumi. Incidence of Hepatitis B Surface Antigen among Sickle Cell Disease Patients Receiving Transfusion Therapy. International Journal of Biomedical Science and Engineering. Vol. 2, No. 1, 2014, pp. 7-10. doi: 10.11648/j.ijbse.20140201.12

\begin{abstract}
Sickle cell disease (SCD) patients deserve serious attention regarding their Hepatitis B status because episodes of jaundice in the disease may be misleading in many cases. It may either be part of the chronic haemolysis they experience or due to blood transfusion (supportive therapy) related hepatotropic viral infections (Hepatitis-B). The aim of the study was to determine the incidence of Hepatitis B virus infection due to transfusion therapy among SCD patients. Venous blood samples were taken from 202 consenting SCD patients. Haemoglobin-electrophoresis was done to determine the sickling status and Haemoglobin $(\mathrm{Hb})$ genotype of each patient. The samples were then tested for Hepatitis B Surface antigen (HBsAg) using the immunochromatographic method. A questionnaire correlating Hepatitis-B infection and history of blood transfusion was used to obtain other data from the patients. Out of 202 patients who participated in the study, 87 were males and 115 females. The Hb genotype distributions were as follows: SS (128), SC (66), S- $\beta$ thal (5), CC (2) and SE (1). 99 out of the 202 had a history of blood transfusion. The frequency of HBsAg in the participants was $3.5 \%$ and the relative risk of infection by blood transfusion was $2 \%$. It was found that sickle cell disease patients are not at a major risk of hepatitis B viral infection due to transfusion therapy because of the use of properly screened donor blood. However, there remains a significant risk by donations from infected donors who have not yet developed detectable HBsAg levels.
\end{abstract}

Keywords: Diagnosis, Hepatitis B Virus, Monitoring, Prevention

\section{Introduction}

Sickle cell disease (SCD) is a haemoglobinopathy characterised by the presence of the sickle haemoglobin $(\mathrm{HbS})$ in association with other abnormal haemoglobin (heterozygote) or as homozygote as in reference [1]. The term disease is applied, because the inherited abnormality causes a pathological condition that can lead to severe complications and even death as in $[1,2]$. Again, SCD is an autosomal recessive genetic blood disorder, characterized by red blood cells that assume an abnormal, rigid, sickle shape under reduced oxygen tension as in reference $[1,2]$. Two genes for the sickle or other abnormal haemoglobin must be inherited from one's parents in order to have the disease as in [3]. SCD can neither be contracted nor passed on to another person as in reference [3].
Sickled cells tend to get stuck in narrow blood vessels, blocking the flow of blood, thus, SCD patients are frequently hospitalised for blood transfusions and are at risk for a lifethreatening complication such as acute chest syndrome as in [4]. A person who receives a gene for SCD from one parent and a normal gene from the other has a condition called sickle cell trait (SCT) and SCT produces no symptoms or problems for most people as in reference [4]. The main genotypes of SCD are: homozygous sickle cell disease $(\mathrm{Hb}$ $\mathrm{SS}$ and $\mathrm{Hb} \mathrm{CC}$ ), sickle cell haemoglobin $\mathrm{C}$ disease (Hb SC), sickle cell haemoglobin E disease (Hb SE) and sickle cell beta-thalassaemia $\left(\mathrm{Hb} \mathrm{S}^{\circ}\right)$ as in reference [4].

Hepatitis B virus (HBV) is the most common cause of serious liver infection in the world. It is estimated that worldwide, more than two billion people have been infected by HBV and 350 million people have chronic infection as in [5]. Hepatitis B can cause an acute or a 
chronic illness. Persons with chronic HBV infection are predisposed to chronic liver disease and have a greater than 200-fold increased risk of hepatocellular carcinoma (HCC) as in [6]. Hepatitis B disease is common in Asia, Africa, China and the Middle East as in [7]. The virus is present in the blood, saliva, semen, vaginal secretions, breast milk, tears, urine and to a lesser extent perspiration of infected individuals as in reference [8].

Patients with sickle cell anaemias (SCA) as a result of $\mathrm{SCD}$ require frequent blood transfusions and are therefore at high risk of infections such as $\mathrm{HBV}$ due in part to improper screening of transfused blood as in [9]. HBV is associated with an increase in clinical severity of sickle cell crisis among SCA patients and runs a more prolonged course in them as in reference [10]. It is also associated with a significantly higher bilirubin levels, and may have contributed to some cases of cirrhosis described in SCA patients as in reference [11]. It is therefore important that SCD patients who receive regular transfusion therapy be tested to determine if they have been exposed to HBV as a result.

\section{Materials and Methods}

\subsection{Study Population}

The study population was made up of two hundred and two (202) sickle cell disease patients who visited the sickle cell clinic at the Korle $\mathrm{Bu}$ teaching Hospital. Out of the total number, 87 were males and 115 females. Again, 128 had $\mathrm{Hb}$ genotype $\mathrm{SS}, 66$ had $\mathrm{Hb}$ genotype $\mathrm{SC}, 5$ had $\mathrm{Hb}$ genotype $\mathrm{S}-\beta$ thal, 1 had $\mathrm{Hb}$ genotype $\mathrm{SE}$ and 2 had $\mathrm{Hb}$ genotype $\mathrm{CC}$.

\subsection{Ethical Consideration}

Ethical clearance for this research was sought from the Ethics and Protocol Review Committee at the School of Allied Health Sciences, University of Ghana, Legon. All the participants gave their informed consent before their samples were collected.

\subsection{Materials}

Some of the materials needed for the work include: Cellulose Acetate Membrane (CAM), Hepatitis B Surface Antigen Rapid Strips, Buffer (Tris EDTA), Stain (PONCEAU S), EDTA Anticoagulated tubes, Gloves, Cotton wool, Syringe and needle, Pasteur Pipettes, 5\% Acetic Acid, 70\% methylated spirit, Electrophoresis tank and Centrifuge.

\subsection{Specimen Collection}

$2 \mathrm{ml}$ of venous blood was taken from each of the two hundred and two (202) consenting SCD patients recruited for the study conducted between June and July, 2012. The blood was transferred immediately into ethylenediamine tetra- acetic acid (EDTA) bottles, mixed well to avoid stasis and labelled with unique ID numbers. Analysis for hepatitis $\mathrm{B}$ virus (HBV) and Haemoglobin ( $\mathrm{Hb})$ electrophoresis to confirm their status then followed as outlined below.

\subsection{Specimen Processing}

For the serologic marking of $\mathrm{HBV}$, the test was conducted with Hepatitis C and B (HCB) Rapid Test Kit obtained from Cortez diagnostics, INC. The blood samples were allowed to settle and two drops of plasma from each specimen was dispensed onto the sample pad of the test strip using a plastic dropper. The timer was started and the coloured bands developed were interpreted after 15 minutes. A negative result was indicated by only one colour band on the control $\mathrm{C}$ region, and no apparent band on the test (T) region. The test sample was positive when both a pinkcoloured control $\mathrm{C}$ band appears in addition to a distinct pink-coloured band in the test $(\mathrm{T})$ region.

For $\mathrm{Hb}$ Electrophoresis, the anticoagulated samples were each washed four times with isotonic saline by centrifugation at $1500 \mathrm{rpm}$ for 5 minutes. After the last wash the supernatant was decanted and with the aid of a Pasteur pipette, eight drops of the packed red cells was added to two drops of diluted saponin. It was mixed well and three drops of carbon tetrachloride $\left(\mathrm{CCl}_{4}\right)$ was added. The mixture was spun at 3000rpm for 15 minutes after 10 minutes of vigorous shaking. The top layer (haemolysate) was removed using a pipette into a clean glass test tube. With the power supply disconnected, the compartments of the electrophoresis tank were filled with Tris Buffer $(\mathrm{pH}$ 7.4) and the two wicks of filter paper were positioned on the bridges. Cellulose acetate membrane (CAM) was soaked in TE buffer $(\mathrm{pH} 7.5)$ in a separate dish for 5 minutes. The CAM was blotted by placing it between two pieces of absorbent paper, but was not allowed to dry. A control sample as well as each of the prepared test samples was applied to the CAM approximately $3 \mathrm{~cm}$ from one end of the membrane using an applicator. The CAM was placed upside down across the bridge of the tank so that the CAM surface is not in contact with the buffer, with the line of application at the cathode (-) end. The power supply was connected and run at $250 \mathrm{~V}$ for 30 minutes and disconnected. The membrane was removed and stained in Ponceau $\mathrm{S}$ for 5 minutes. It was removed, drained and excess stain removed with 3 changes of destaining solution for two minutes each. The membrane was then dehydrated in absolute methanol for three minutes. It was immersed in clearing solution for six minutes, dried at $65^{\circ} \mathrm{C}$ in a hot air oven for four minutes. The membrane was labelled and the results read against the controls.

\subsection{Data Analysis}

Data collected was analyzed using the Statistical Package for the Social Sciences version 17 (SPSS 17) and Microsoft Office Excel 2007. 


\section{Results}

In this study, male participants were 87 representing $43.1 \%$ and female participants were 115 representing $56.9 \%$.

Table 1: A table showing the Hb genotypes of participants.

\begin{tabular}{ccc}
\hline Hb genotype & Frequency & Percentage \\
\hline SS & 128 & 63.4 \\
SC & 66 & 32.7 \\
S- $\beta$ thal & 5 & 2.5 \\
SE & 1 & 0.5 \\
CC & 2 & 1 \\
Total & 202 & 100 \\
\hline
\end{tabular}

From the table above, we see that $\mathrm{Hb} \mathrm{SS}$ patients made up more of the study group followed by HbSC, S- $\beta$ thal, $\mathrm{CC}$ and SE.

Table 2: A table representing history of blood transfusion amongst study subjects.

\begin{tabular}{ccc}
\hline & Frequency & Percentage \\
\hline YES & 99 & 49 \\
NO & 103 & 51 \\
Total & 202 & 100 \\
\hline
\end{tabular}

Table 3: A table representing participants and episodes of sickle cell crisis.

\begin{tabular}{ccc}
\hline $\begin{array}{c}\text { Sickle cell } \\
\text { Crisis }\end{array}$ & Frequency & Percentage \\
\hline YES & 161 & 79.7 \\
NO & 41 & 20.3 \\
Total & 202 & 100 \\
\hline
\end{tabular}

The table shows that many of the patients have been experiencing frequent crisis.

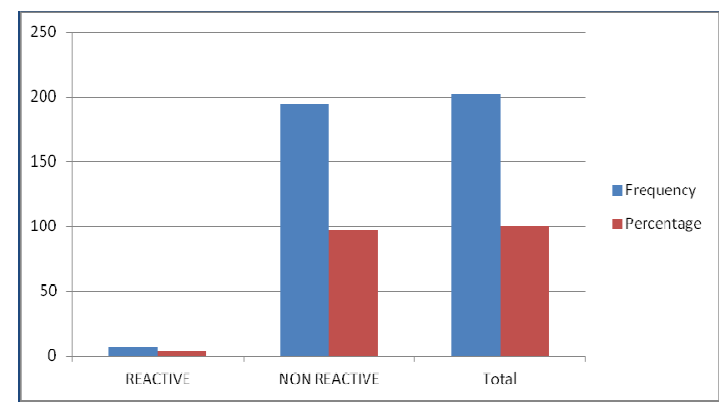

Fig. 2: A graph representing $H B s$ Ag reactivity. 7 subjects representing 3.5\% of the study population were reactive with HBsAg whilst 195 representing $96.5 \%$ were non-reactive.

\section{Discussion}

There are episodes of jaundice in sickle cell disease (SCD) patients which may be misleading in many cases. This is because it may either be part of the chronic haemolysis they experience or due to transfusion related hepatotropic viral infections (Hepatitis B), thus the need for Hepatitis B viral testing among SCD patients who receives transfusion therapy.

In this study, it was seen that 7 subjects $(2$ male and 5 females) were seropositive to rapid immunochromatographic HBsAg test representing 3.5\% of the study population. 195
(85 males and 110 females) were however seronegative representing $96.5 \%$. Out of the 7 seropositive subjects, 2 had history of blood transfusion whilst 97 of the seronegative patients also had history of blood transfusion. This means about $2 \%$ of patients with a history of blood transfusion out of the study population had HBsAg. Our results therefore indicated a relative risk of $2 \%$ of HBsAg infection by blood transfusion.

This rate is considered low in relation to the study done by Berenguer and Wright where HBsAg positivity was more than $8 \%$ in countries which include the Far East, parts of the Middle East, Sub-Saharan Africa and the Amazon Basin perhaps due to study population size as in reference $[12,13]$. The result of this study is however close to that of a recent one done on children at the Komfo Anokye Teaching Hospital, in Kumasi, Ghana, which was found to be $3.6 \%{ }^{10}$.

In another study conducted at the National Blood Transfusion Service, Accra, Ghana, between June and August 1999, the HBV seroprevalence rate for blood donors was estimated to be $15.0 \%$ by routine pre-donation screening as in reference [14]. The lower prevalence of the HBsAg in SCD patients seen in this study compared to the general population could be attributed to a better education of the sickle cell patients and caregivers as well as better screening techniques for $\mathrm{HBsAg}$ in blood transfusion centres as in reference [10].

\section{Conclusion}

Blood transfusion as a form of supportive therapy given to SCD patients does pose a relative risk of them being infected with HBV. The $3.5 \%$ prevalence seen in all the study subjects and the $2 \%$ in those with a history of blood transfusion, suggests that HBV infection during transfusion should not be completely ruled out. There remain significant risks from infected donors who have not yet developed detectable HBsAg levels. HBV screening and vaccination should therefore be a part of the management of SCD patients.

\section{Acknowledgements}

We are grateful to the Sickle Cell Clinic of the Korle-Bu Teaching Hospital for providing us with the samples and the Haematology Laboratory of the School of Allied Health Sciences for their help in analyzing them.

$\begin{array}{ll}\text { Abbreviations } \\ \text { ANTI-HBC } & \text { Hepatitis B Core Antibody } \\ \mathrm{CAM} & \text { Cellulose Acetate Membrane } \\ \mathrm{CTL} & \text { Cytotoxic T-Lymphocyte } \\ \mathrm{EDTA} & \text { Ethylenediaminetetraacetic Acid } \\ \mathrm{Hb} & \text { Hemoglobin } \\ \mathrm{Hb} \mathrm{S} \beta^{\circ} & \text { Sickle Cell Beta-thalassaemia } \\ \mathrm{HBV} & \text { Hepatitis B Virus } \\ \mathrm{HBSAG} & \text { Hepatitis B Surface Antigen }\end{array}$




$\begin{array}{ll}\text { HBeAG } & \text { Hepatitis E Antigen } \\ \text { HBcAG } & \text { Hepatitis B Core Antigen } \\ \text { HCC } & \text { Hepatocellular Carcinoma } \\ \text { HLA } & \text { Human Leukocyte Antigen } \\ \text { SCA } & \text { Sickle Cell Anaemia } \\ \text { SCD } & \text { Sickle Cell Disease } \\ \text { SPSS } & \text { Statistical Package for the Social Sciences }\end{array}$

\section{References}

[1] Desai DV and Hiren D (2004). Sickle Cell Disease: History and Origin. The Internet Journal of Haematology 1 (2).

[2] Al Adnani MS, Al Kasab FM and Al Alusi FA (1982). Hepatitis B surface antigenaemia in sickle cell disease. Lancet 2:1286.

[3] Clarke G and Higgins T (2000). Laboratory investigation of hemoglobinopathies and thalassemias: review and update. Clin. Chem. 46 (8 Pt 2): 1284-90.

[4] Chowning JT (2000). Sickle Cell Anemia Case Study: Summary. BioLab, Seatle, WA, Accessed on December 2003 from Http://genetics-educationpartnership. mbt.washington.edu/download/sicklecell.pdf.

[5] Drosten C, Nippraschk T and Manegold C (2004). Prevalence of hepatitis B virus DNA in anti- HBCpositive/HBsAg-negative sera correlates with $\mathrm{HCV}$ but not HIV serostatus. J ClinVirol 29: 59-68.

[6] Pyrsopoulous N and Reddy K. Hepatitis B (2012). WebMD LLC: http://emedicine.medscape.com/article/177632.

[7] Maddrey WC (2001). Hepatitis B-an important public health issue. Clin. Lab. 47(1-2):51-55.

[8] Lok AS (2002). Chronic hepatitis B. N Engl. J. Med 346 (22):1682-1683.
[9] Wallis JP, Wells AW, Matthews JN, Chapman CE (2004). Long-term survival after blood transfusion: a population based study in the North of England. Transfusion; 44: 102132 .

[10] Nsiah K, Dzogbefia V P, Osei-Akoto A and Ansong D (2012). The prevalence of seropositivity to hepatitis B surface antigen and the corresponding hemato-biochemical features in sickle cell patients in Ghana. Journal of Hematological Malignancies 2: 1

[11] Chamberland M, Alter HJ, Busch MP, Nemo G, Ricketts M (2001). Emerging infectious disease in blood safety. Emerg. Infect. Dis; 7: 552-3.

[12] Ampofo W, Nii-Trebi N, Ansah J, Abe K, Naito H, Aidoo S.et al (2002). Prevalence of Blood- Borne Infectious Diseases in Blood Donors in Ghana. J Clin Microbiol 40(9): 3523-3525.

[13] Amidu N, Alhassan A, Obirikorang C, Feglo P, Majeed SF, Timmy-Donkoh E. et al (2012). Sero-prevalence of hepatitis B surface ( $\mathrm{HBsAg}$ ) antigen in three densely populated communities in Kumasi, Ghana. Journal of Medical and Biomedical Sciences 1(2): 59-65.

[14] Berenguer M and Wright TL (2002). Sleisenger \& Fordtran's Gastrointestinal and Liver Disease Pathophysiology/Diagnosis/Management, 7th ed. Philadelphia: Elsevier Science.

[15] Allain JP, Candotti D, Soldan K, Sarkodie F, Phelps B, Giachetti C. et al (2003). The risk of hepatitis B virus infection by transfusion in Kumasi, Ghana. Blood 101: 2419- 2425.

[16] Adjei A, Armah H, Gbagbo F, Ampofo W, Quaye I, Hesse I. et al (2006). Prevalence of human immunodeficiency virus, hepatitis B virus, hepatitis $\mathrm{C}$ virus and syphilis among prison inmates and officers at Nsawam and Accra, Ghana. J Med Microbiol 55(5): 593- 587. 